
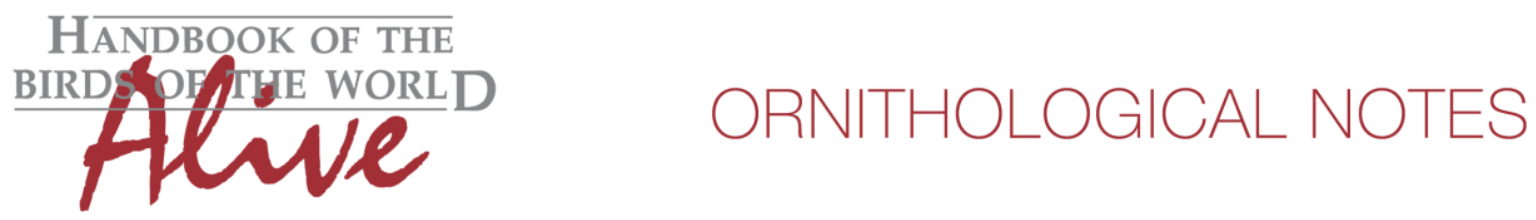

\title{
Notes on the vocalizations of Thrush-like Antpitta (Myrmothera campanisona)
}

\author{
Peter Boesman
}

In the following we briefly analyze and compare voice of the different races of Thrush-like Antpitta (Myrmothera campanisona). We also try to quantify the extent of any vocal differences using the criteria proposed by Tobias et al. (2010), as a support for taxonomic review. We have made use of sound recordings available on-line from Xeno Canto (XC).

Song of all races is structurally similar, but subcanescens clearly differs in a number of features (Fig. 1). We have therefore taken some measurements of the basic sound parameters to compare subcanescens with the other races treated as a single group:

$\begin{array}{ll}\begin{array}{ll}\text { subcanescens }(n=7) \\ \text { max. note length }\end{array} & 0.17-0.25 \mathrm{~s} \\ \text { max. mid freq. } & 1080-1220 \mathrm{~Hz} \\ \text { end freq. } & 1080-1220 \mathrm{~Hz} \\ \text { freq. change } & +60 \text { to }+140 \mathrm{~Hz} \\ \text { last note length } & 0.16-0.25 \mathrm{~s} \\ \text { \# notes } & 5-9 \\ \text { highest amplitude } & \text { last or last but one note } \\ & \\ \text { others ( } n=12) & \\ \text { max. note length } & 0.18-0.28 \mathrm{~s} \\ \text { max. mid freq. } & 750-950 \mathrm{~Hz} \\ \text { end freq. } & 750-920 \mathrm{~Hz} \\ \text { freq. change } & -90 \text { to }+30 \mathrm{~Hz} \\ \text { last note length } & 0.15-0.24 \mathrm{~s} \\ \text { \# notes } & 6-10 \\ \text { highest amplitude } & \text { fourth, third or second last note }\end{array}$

Song of subcanescens is clearly higher-pitched (score 3 ) and rises towards the end (score 2). Furthermore, the max. amplitude is reached on the last or last but one note (score 1-2). Also the last note of the song does not become shorter, which is often the case in other races.

From the other races, dissors seems to have the highest pitch (XC163576 is probably not modesta but also dissors), but still clearly lower than subcanescens, and lacking the other features of subcanescens.

Total score for vocal difference between subcanescens and other races is thus 4-5. 

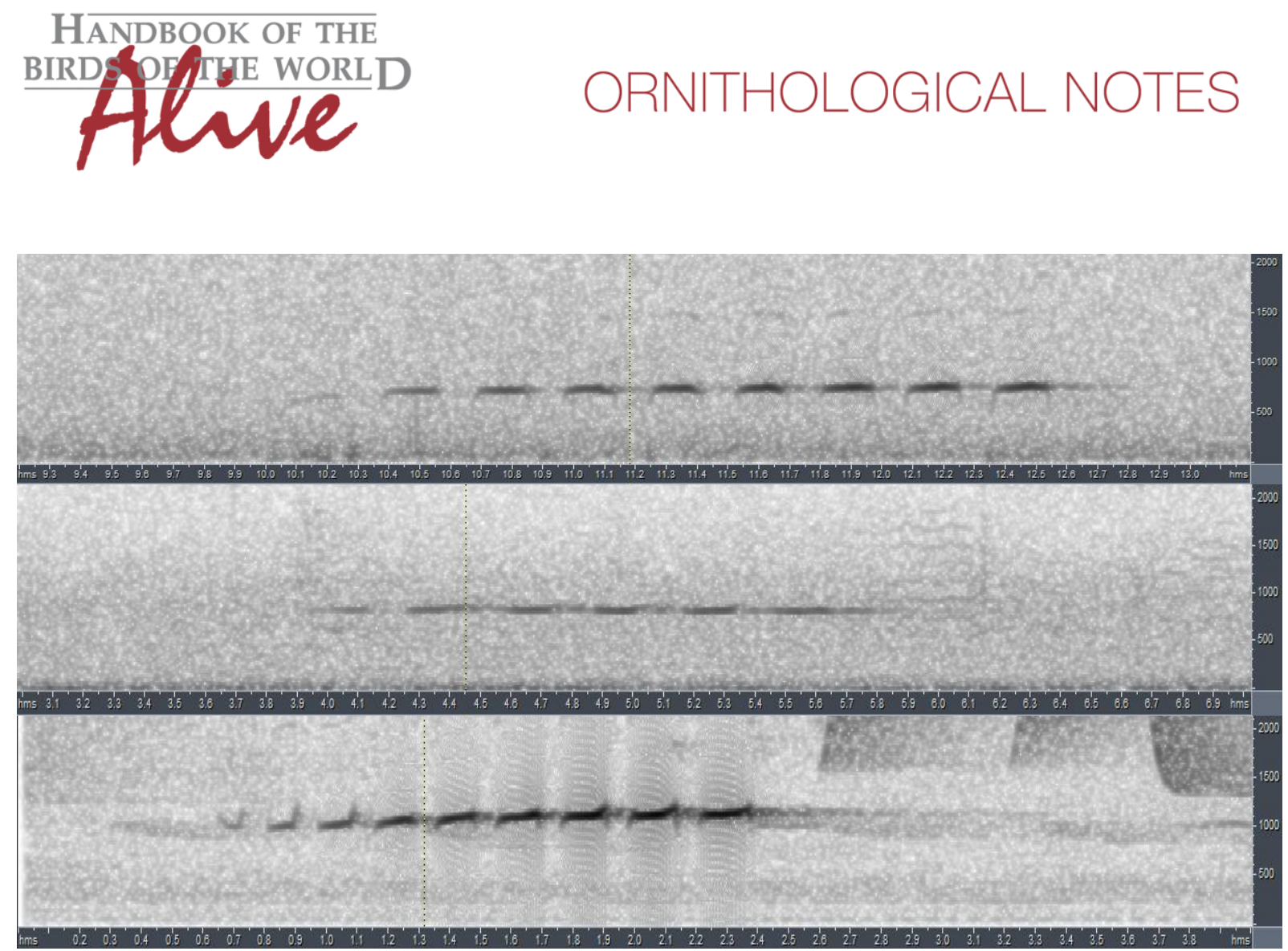

Figure 1: From top to bottom: Song of nominate, dissors and subcanescens

This note was finalized on 15th June 2015 , using sound recordings available on-line at that moment. We would like to thank in particular the many sound recordists who placed their recordings for this species on XC.

\section{References}

Tobias, J.A., Seddon, N., Spottiswoode, C.N., Pilgrim, J.D., Fishpool, L.D.C. \& Collar, N.J. (2010). Quantitative criteria for species delimitation. Ibis 152(4): 724-746.

\section{Recommended citation}

Boesman, P. (2016). Notes on the vocalizations of Thrush-like Antpitta (Myrmothera campanisona). HBW Alive Ornithological Note 74. In: Handbook of the Birds of the World Alive. Lynx Edicions, Barcelona. (retrieved from http://www.hbw.com/node/931962 on 18 May 2016). 